\title{
An Exploratory Approach to the Influence of Perceived Social Presence on Consumer Trust in a Website
}

\author{
Mouna Thabet and Mustapha Zghal
}

Faculty of Economics and Management at Tunis-Tunisia

Received 3 March 2012; Accepted 2 April 2012; Published 22 January 2013

Academic Editor: Leger Jarniou

\begin{abstract}
Online trust has been widely discussed in the marketing research area and mainly in these two forms namely: trust toward internet technology and trust toward an online merchant. Nonetheless, very few studies have examined a very particular form of an online trust that is trust in a merchant website.

Also, the literature examination revealed the importance of social presence in e-commerce. To this end, this research focuses on the one hand, to identify the dimensions of trust in a merchant website. On the other hand, it aims to explore different forms of perceived social presence on a website and determine their respective impacts in the formation of consumer trust toward a retail website. The results of a qualitative study in the form of semi-structured interviews, conducted with thirty individuals show that trust in a commercial website includes both two types of dimensions: trust beliefs and trust intentions. In addition, different manifestations of online social presence were identified namely: FAQ forums, animations, instant messaging, website data, the number of registered on the website, human pictures, personalized welcome and virtual agents. Likewise, the results show that the online social presence is an antecedent of trust toward a retail website.
\end{abstract}

Keywords: Trust toward a retail website, online social presence, electronic commerce, content analysis.

\section{Introduction}

Based on the literature review, humans look for reducing social uncertainty. In other words, they are looking for ways to understand, predict and sometimes control the behavior of others. When the individual fails to reduce uncertainty through social rules and customs, he first uses the concept of trust or a higher degree of familiarity that constitute methods of reducing social complexity (Luhmann , 1979).
Indeed, trust is still the main distinctive feature of human interaction (Blau, 1964; Luhmann, 1979) especially when the outcomes of interactions with others are not entirely governed by rules and safeguards (Thibaut and Kelley 1959; Blau, 1964, Kelley and Thibaut, 1978; Kelley, 1979).

Trust also occupies a central position in many commercial activities (Dwyer et al., 1987, Fukuyama, 1995; Reichheld and Schefter, 2000) particularly when the

Copyright (C) 2013 Verstraete Maud, Debucquoy Annelies, Sagaert Xavier, Van Cutsem Eric and Haustermans Karin. This is an open access article distributed under the Creative Commons Attribution License unported 3.0, which permits unrestricted use, distribution, and reproduction in any medium, provided that original work is properly cited. Contact author: Verstraete Maud E-mail: thabetmouna@yahoo.fr 
trustor has no control over the trustee. Consequently, the trust can be a substitute for formal agreements in established exchange.

According to this, trust is required more acute in electronic commerce. Firstly, it is due to the scarcity of regulating rules and practices. Secondly, it is because of the lack of physical contact with both products offered online and the internet merchant. In fact, research has shown that high levels of consumer trust stimulates online purchase intentions (Jarvenpaa and Tractinsky, 1999; Gefen 2000) and helps to maintain its online customers (Reichheld and Schefter, 2000). Conversely, the lack of trust is the major obstacle to transacting online (Hoffman, Novak and Peralta 1999).

In light of the economic and social conception of trust, it is clear that this concept thrives through direct contact between exchange partners which is congruent with Handy (1995) axiom "trust needs touch". Really, this theorist emphasizes the importance of social contact for the formation and the growth of trust.

However, unlike face-to-face provided by traditional commerce, trade on the internet is characterized by the absence of direct interpersonal interactions. In this context, human interactions or social cues lack many commercial websites (Reichheld and Schefter, 2000). The literature review has revealed the existence of a variable closely related to the context of electronic commerce: online social presence. This human presence is an accelerating lever for the expansion of electronic commerce (Hassanein and Head, 2007, Wang et al., 2007; Brial, 2010). At this level, two main questions arise: in a context characterized by a lack of human interactions, how trust is built into a retail website? What extent social presence contributes to the formation of this form of trust?

Given these contextual specificities, first, this research attempts to examine the nature of trust in a merchant website highlighting its various aspects. Then, we wonder about the existence of a sense of social presence on a website that can address the lack of social interaction and posing as a precursor to the formation of trust in a merchant website. All the more, the field of investigation in this area remains largely unexplored by researchers.

It shall be noted that this research fits into the logic of a better understanding of the online purchase behavior. To our knowledge, very few works that remain have addressed trust in a retail website unlike most researchers who are interested in the study of trust in an online vendor. To investigate the characteristics of trust in a merchant website, an exploratory qualitative study is conducted. It aims to identify the dimensions of this form of trust and explore the manifestations of this "need for contact" required by users in a virtual shopping. For this purpose, the first part is dedicated to the presentation of two central concepts: trust in a retail website and perceived social presence in a website. The second part presents the relationship between these two variables.

\section{Literature Review}

\section{Conceptualization of Trust in a Merchant Website}

Recently, Bartikowski, Chandon and Müller $(2008,2010)$ researches are an example in the adaptation of interpersonal vision proposed by McKnight et al. (2001-2002) to a retail website case. A priori, these authors saw a commercial website more than a sales support. They measured trust toward a merchant website through beliefs (competence, integrity and benevolence) and trusting intentions (willingness to depend on the website, willingness to follow the advice offered by the website, willingness to share information with the website and willingness to make purchase from the website).

We note that this interpersonal approach involving the individual in his relationship with a website was discussed in the theory of social response proposed by Nass et al. (1997). This theory states that an individual tends to apprehend the computer as a social actor even knowing 
that he is not in the presence of a human being (Moon, 2000; Lemoine and Notebaert, 2009). In view of the paradigm "computers are social actors" (CASA) founded by Nass, Steuer, Tauber and Reeder (1993) and Nass, Steuer and Tauber (1994), the social laws governing human interactions are the same underlying interactions of humans with their computers.

Proponents of this paradigm argue that a person can enforce standards of civility to his computer because it makes him praise from its performance. They add that people can also assign "gender stereotypes" to their computers. In this sense, Green (1993) states that, for example, a male voice from a computer is perceived as more convincing than feminine voice while the latter is seen as more effective in expressing feelings of affection.

Also, Nass et al. (1994) conclude that social norms can be applied to a computer to make a social actor. In this sense, the authors perceive the computer as a teammate who are assigned responsibilities such as: cooperation, alignment with team spirit, an attitude, a socially correct, etc. Other researchers have gone to the allocation of human personalities to computers (Nass et al., 1995).

It thus appears clear that CASA has its roots in the doctrine of "anthropomorphism" in the sense that the person deals with technology as it is in the presence of a human being and then all theories applied through interpersonal are valid in this case (Nass et al. 1995).

The CASA paradigm assigns a human portrait technology, on the basis of some cues: dominant, warm, competent, hostile, etc. Recently, Wang et al. (2007) have assimilated the human interaction to the interactivity with a website and these researchers were able to study even the degree of sociability of a website. Similarly, such conceptions of online trust have been reflected in recent years in some writings (Lemoine et Notebeart, 2009; Batikowski, Chandon and Müller (2010) who allotted the concept of interpersonal trust to the concept of trust toward a retail website.

Based on these findings, all visions characterized the controversy of trust in retail website are summarized in the figure below:
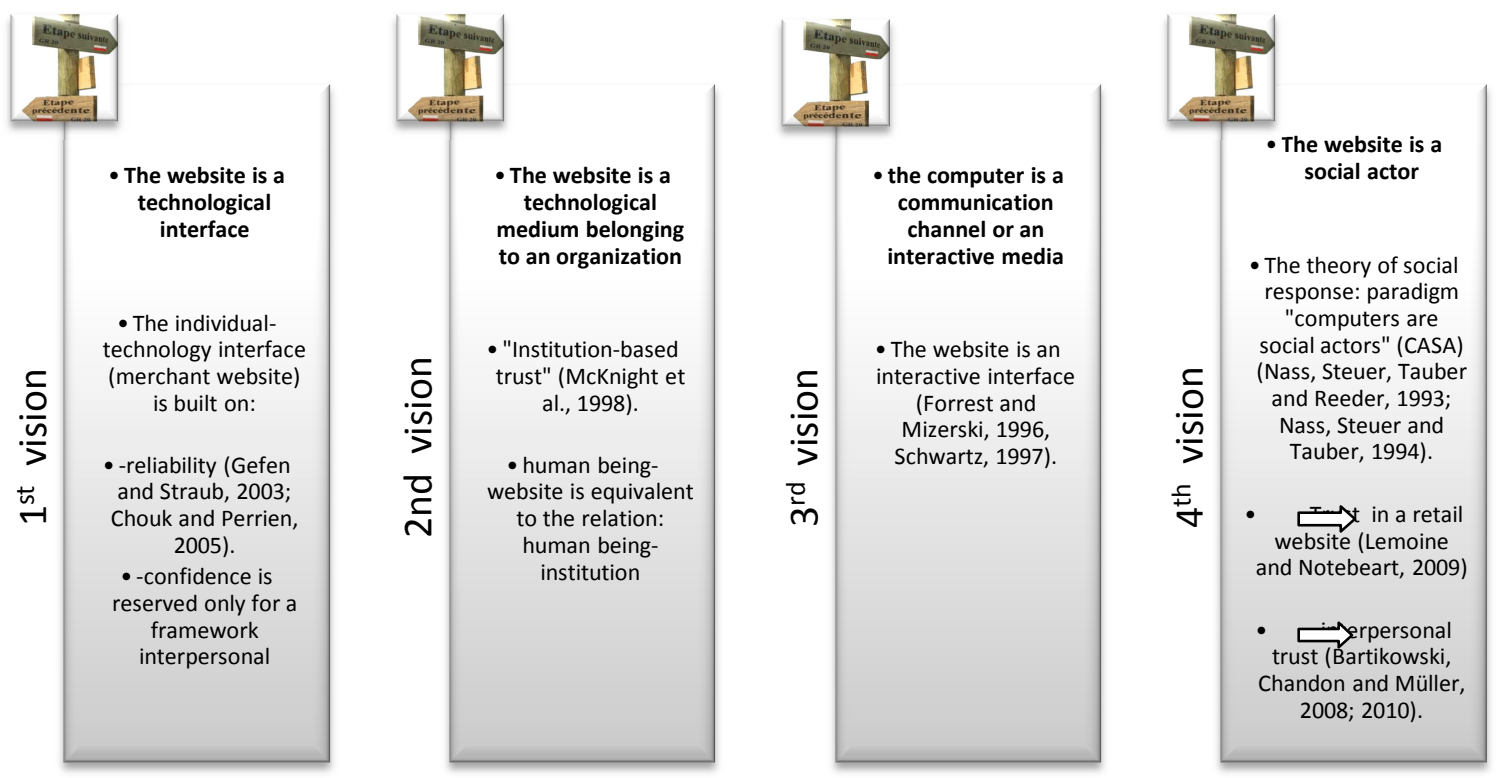

Fig 1. Different Approaches of Trust in Retail Website 
We note that the CASA paradigm is applicable to Internet technology in a broad sense and websites in a narrower sense. That is why trust toward website is relevant and denying the thesis refuting the principle of relationships between human beings and technology. Therefore, a proposal for trust definition adapted to this context is provided.

\section{Proposed Definition of Trust in a Retail Website}

By analogy to the traditional transactional context, trust in a virtual environment is characterized by uncertainty, vulnerability and dependence. Being fundamentally no different from the off-line trust, online trust presents a more acute vulnerability. This is due to the perception of risk associated with the lack of "real" evidence to ensure that the e-vendor shall not engage in opportunistic behavior (Gefen and Straub, 2003).Therefore, trust is perceived more critical in the context of electronic commerce.

Earning the trust as an expectation, Corbitt et al. (2003) state that online trust is presented as "the expectation that others will behave in accordance with their commitments, negotiate honestly and do not take advantage of the situation even if the opportunity presents itself" (p.204).

Other studies adopt the notion of belief to describe the nature of the trust. McKnight et al. (2001-2002) conceived the trust in an online merchant as "the belief that allows consumers to voluntarily be vulnerable to an internet merchant after taking into consideration the characteristics of this merchant" (p.42). This approach of trust highlights two key concepts: trust as a set of beliefs and trust as a behavioral intention. By adopting a merchant website vision, These beliefs are attributed to the competence of the website (user perception abilities, skills and expertise of the website), the integrity of the website (the belief that website fulfills its promises, accomplishing its ethical obligations as the delivery of goods and services or their confidentiality with respect to information disclosed) and the benevolence of the website (the belief that the website does not take advantage of the vulnerability of the client and is in the interest of its customers in Instead of worrying maximize its profit). These attributes relating to the reliability of a merchant website are the most cited and used in research on the study of trust (Mayer et al., 1995; McKnight et al., 2002). They lead the intentions of commitment in a relationship of trust that occur in "the willingness of a consumer to be vulnerable to the actions of an online store based on its expectations that it will act in the interest of consumers without account of its ability to monitor or control the online store "(Hsu, 2008: 4). On the intentional aspect of trust, Schoorman et al. (2007) present the trust as "the willingness to take risks." To McKnight et al. (2002), intends to engage in a relationship of trust is a result of the perception of beliefs based trust. They add that this intention is expressed through: acceptance to depend on the website (e.g. to have the service provided by the site if necessary), will follow the advice provided by the site (e.g. to use the advice given by the technicians of the site if needed), be willing to share their personal data with the site (e.g. communicate personal information to the site and its private information) and purchasing intention from the site). Bartikowski et al. (2008) have extended this concept by adding the intention to recommend the site to friends.

For a better understanding of the concept of trust, we choose to adopt the definition of Moorman et al. (1992) that combines all these approaches cited in the literature to assert a more complete and more relevant definition. We propose the definition of integrative trust in a retail website stating that "trust is the willingness of the user to depend on a merchant website on the basis of certain beliefs or expectations arising from the competence, the integrity and the benevolence perceived in this website "(adapted from the definition of Moorman et al. (1992, p.315). 


\section{Social Presence: The Experience of "Being with Others" in a Mediated Environment}

A main characteristic of a mediated communication is attributed to the feeling of an individual to be present with another person (Biocca et al., 2003). For the authors, a sense of human presence emerges through a set of pixels in the shape of a smiling face, a voice seeping through a speaker, or a text from an online discussion and displayed on the screen. Indeed, social presence can be defined as "the phenomenal sense of being there with another person, or feel the presence of another person through a medium "(Biocca, Harms and Burgoon, 2003, p.456).

Also, in a context of an online exchange, social presence can be considered a degree of sensation, the perception and the reaction of an intellectual entity to be connected to a computer through other intellectual entity on the basis of a text (Tu and McIsaac, 2002).

The degree of social presence is not only determined by the environmental characteristics and users' perception (Tu, 2002a; Tu and McIsaac, 2002), but also through the users' activities (Tu, 2002a).

The perception of online social presence is influenced either by a set of determinants namely: social relationships, trust, or the user characteristics and perceptions of mediated environments, the attributes of media communication, use of paralanguage and emotions, communication styles and privacy (Tu, 2002b). The notion of "being socially present" or "socially absent" has gained attention with the advent of telecommunications technology (Scarpetta, 2008). In an attempt to give a unanimous definition of social presence, researchers tried to answer the fundamental question: what does it mean that a person is socially present? Approaches to dealing with social presence in the field of marketing research have implemented mainly three forms of presence: physical, psychological and behavioral.
Otherwise, the modality of physical presence contains a dichotomy either a person is present in an environment, or he is absent in the same environment (Huguet, Galvaig Monteil and Dumas, 1999). This definition has been expanded by the design of co-presence proposed by Goffman (1959) which focuses on the ability of a medium to convey the sense of mutual presence. The author states that "the copresence makes people accessible, available and at the disposal of another" (Goffman, 1959, p.22).

To measure the presence of synchronous sensation felt by some people, a little effort was developed by some researchers. They suggested series of questions such as: To what extent did you have the feeling of being in the same room as your partner?" (Schroeder et al., 2001). Beyond the conventional sense of the physical presence, which persists as a fundamental of social presence, psychological shading arises. It focuses on the psychological commitment (Biocca et al., 2003). Being present with others means that we feel a certain psychological involvement with them. According to the principles of psychological involvement, the sense of access to intelligence, the salience of interpersonal relationships, intimacy and immediacy and mutual understanding are the manifestations of this dimension (Scarpetta, 2008). The author replied that the psychological presence is related to a sense of involvement in a relationship, a state of mind, an affinity and similarity emotional and attitudinal regarding another. Examples of this commitment in relation to psychological social presence were presented by Biocca, Harms, and Gregg (2001) such as "When I was happy, the other was happy" or "The opinion of the other was clear to me".

Finally, the behavioral definition of social presence alleges that the individual is present when he displays a behavioral commitment "My behavior was a direct response to his behavior" (Biocca, Harms, and Gregg, 2001). This behavioral dimension corresponds to the feeling of a synchronized and coordinated interaction 
between the parties governed by a look, non-verbal actions, taking a role and so were considered prerequisites for social presence (Garau, 2006).

On the basis of an action approach, the environment is defined as "Place is the set of resources organized and transformed by the involvement in human action in any certain moment" (Spagnolli and Gamberini, 2005 , p.8). It should be noted that "resources" may include both the physical and symbolic elements (Spagnolli and Gamberini, 2005).

Symbolic elements are social cues communicating the presence of others in a mediated environment (Scarpetta, 2008).

By comparing the influence of different types of communication media in relation to the transmission of social presence feeling, Short et al. (1976) support the idea that each environment has a different degree of social presence which significantly affect social interactions (Kim et al., 2009). In the same way, Short et al. (1976) define social presence as the ability of a medium to transmit a number of socioemotional cues.

In the literature, a few researchers have used social presence as a construct for evaluating human interactions in virtual communities (Khalifa and Shen, 2004; Zhu et al., 2006). In the presence of a transaction channel characterized by the physical absence of the seller, the virtuality of products and the risky nature of the context, the vulnerability increases. Consequently, a need to trust is imposed with more acute. In fact, the consumer is sensitive to any stimulus that could guide buying behavior on the website. Recognizing the crucial role of trust in an online purchase, Reichheld and Schefter (2000, p.107) argue that "price does not rule the web; trust does". To this effect, the company is brought to cogitate on the question how to integrate the concept of social presence in a retail website in order to generate users' trust?

Based on a literature review, it is clear that social presence has a positive impact on the identification of users with online groups and communities (Schimke, Stoeger and Ziegler, 2007) and their intention to participate in online interactions (Tu \& McIsaac, 2002).

Similarly, Gefen and Straub (2004) argue that even a website is devoid of really human interaction, the perception that there is a social presence increases online trust. This suggests that the perception of a presence similar to interpersonal interaction is probably important in ecommerce where customers interact with the website as a physical seller. Also in the context of e-commerce, Karahanna and Straub (1999) have used a social presence to explore the origins of perceived usefulness and perceived ease of use in an emailing system. On their side, Kumar and Benbasat (2002) have demonstrated the significant impact of social presence on the perception of the website usefulness.

Fortin and Dholakia (2005) were able to explain attitudes and intentions related to an online purchase through online social presence. In addition, some solid research highlighted the positive impact of social presence on online trust. Spencer (2001) has shown that social presence has an influence on trust in e-learning context. In the context of online shopping, Pavlou et al. (2005) have highlighted the positive impact of social presence on trust toward the internet vendor.

In order to increase the perception of social presence in websites, the designers have used, among others, human pictures (Riegelsberger and Sasse, 2001; Riegelsberger, Sasse and McCarthy, 2003; Steinbrück, Schaumburg, Duda and Krueger, 2002). Nevertheless, the results of various empirical studies have led to conflicting conclusions. Indeed, Steinbrück et al. (2002) show that the inclusion of photos of human beings on a website is effective in creating a social presence approaching a relationship face-to-face and promoting the reliability of the Internet merchant. However, Riegelsberger et al. (2003) have shown that the presence of pictures on a website has no effect on online trust in a sense that their inclusion can be seen by users as cumbersome. So, 
the lack of consensus about the role of social presence in online trust leads us to examine the manifestations of the online social presence and to study the impact of each of these events on the trust toward a retail website. Therefore, we conducted an exploratory qualitative study to deepen further on the issue.

\section{Study Methodology}

We conducted the semi-structured interview in French. Furthermore depth exploration reached and the wealth of information collected, this investigative tool provides more accurate results obtained since it is centered on specific themes (Evrard et al., 2003)

The sample size of 30 individuals is determined by the saturation criterion of Mucchielli (1991) claiming that after a certain time of the qualitative analysis, there is a redundancy: collected data no longer present news. In our case, the saturation point is reached after thirtieth interview. The sample is composed of buyers and non-buyers online who are users of the Internet technology, men and women aged 25 to 55 years (see Appendix). The choice of the sample is based on three criteria considered relevant to our research: (1) all respondents are users of the internet, (2) they all have a personal bank account, providing them some financial autonomy and (3) all respondents perfectly mastered the French language and to express themselves easily during the interview. These interviews were brought online by means of a video conference on Skype and have an average duration of 50 minutes.

The interviews were conducted by taking a guide to support setting six themes with respondents:

-The use of the Internet in general

- General attitude of the user about online purchasing.

-Importance allocated by the user to the face-to-face interacting in a trade.

-Perception of the notion of trust in a retail website

-Perception of social presence on a retail website

-Role of online social presence in the determination of consumer trust toward a website

Concerning the analyzed data, a content analysis is carried out where the unit of analysis is the theme. To this end, a horizontal thematic analysis aided software TROPES V8 is applied. It seems the most suitable for our study because this qualitative exploratory study has two objectives. First, it's to identify all aspects of social presence and trust toward a retail website (descriptive). Then, it's to show the relationship between these two elements studied (structural) (Descamps, 1987).

\section{Results of the Study}

In what follows, we will explore the concept of trust in a retail website as it is perceived by consumers. Subsequently, we strive to identify manifestations of social presence which are likely to affect the trust in this website before concluding.

\section{How Consumers Perceive Trust in a Commercial Site?}

Firstly, it should be noted that content analysis has confirmed the important role of trust in the context of electronic commerce. It confirms the presence of all dimensions given in the model of McKnight et al. (2002) applied in the case of trust in online vendor and adapted by Bartikowski et al. (2008) for the case of trust in a commercial website.

\section{Definition of Trust in a Retail Website}

Extracts from the verbatim obtained show that trust is both a belief and an expectation. In the light of the content analysis, trust is a positive expectation of the consumer that the retail website will be in line with its expectations and doesn't 
exploit his vulnerability (associating a website to a real vendor) "well, the basis of trust is the opposite of a scam to me ... for me trust in his conduct as in reality " (individual 20), " ... I expect a correct and reliable website... "(individual 1).

\section{Dimensions of Trust in a Commercial Website}

Likewise, content analysis has identified trust as a set of beliefs: it identified an assortment of characteristics related to a retail website encouraging consumers to perceive as reliable or worthy "... So that I can trust a website, I really find evidence of trust in the website that reflects its serious ..." (individual 20). These mainly attributes are: the competence, the integrity and the benevolence. These beliefs translate in trusting intentions. It might be noted that all dimensions of trust mentioned in the literature are cited. In addition, a new dimension of trusting intentions in the website has been mentioned in the transcript as follows: willingness to take risks.

Literature has relied on two different notions of risk taking: the trust as a willingness to take risks (Johnson-George and Swap, 1982; Sitkin and Pablo 1992;
Mayer et al., 1995) and trust as risk taking in a relationship (Blau 1964; Holmes and Rempel 1989, Hardin 2001). Given the difficulty of asking respondents to behave actual risk-taking, this study is more interested in revealing the acceptance of vulnerability among Internet users through a revelation of their predisposition to take a risk.

Based on the analyzed corpus, users seem to be aware of the increased risk concept in a virtual environment "with virtuality, the risk increases ..." (individual 27). In fact, trust is related due to the acceptance of risks taking, which be reflected through users the willingness to communicate personal data "I can't take the risk with any site I found, with only one to I trust as I will take the risk to provide my PIN credit card and only GOD knows what will happen to me if I come across crooks "(individual 19). This willingness to take risk may be financial, as stated by the same respondent "Well, even I think your site is trustworthy and as I have said earlier, I can't venture a sum of only 30 or $40 \mathrm{D}$ to buy on the internet".

All these trust dimensions are summarized in details in Table No. 1 below: 
Table 1. Dimensions of Trust in an Online Shop: Meanings and Frequencies (Thabet and Zghal, 2012)

\begin{tabular}{|c|c|c|c|c|}
\hline & Dimensions & Meanings & $\begin{array}{c}\text { Frequency of } \\
\text { occurrence in the } \\
\text { verbatim }\end{array}$ & $\begin{array}{c}\text { Percentage of } \\
\text { occurrence in the } \\
\text { verbatim }\end{array}$ \\
\hline & $\begin{array}{l}\text { Website } \\
\text { Competence }\end{array}$ & $\begin{array}{l}\text { seriously, expertise, } \\
\text { professionalism, skill, expertise }\end{array}$ & 13 & $18 \%$ \\
\hline \multirow[t]{3}{*}{ 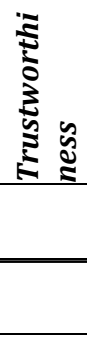 } & $\begin{array}{l}\text { Website } \\
\text { benevolence }\end{array}$ & $\begin{array}{l}\text { respect for the customer } \\
\text { willingness to help its customer, } \\
\text { assistance from the website, an } \\
\text { advisor to the consumer, the } \\
\text { consumer's interest. }\end{array}$ & 11 & $15.3 \%$ \\
\hline & $\begin{array}{l}\text { Website } \\
\text { Integrity }\end{array}$ & $\begin{array}{l}\text { Honesty, transparency, credibility, } \\
\text { respects its commitments. }\end{array}$ & 8 & $11 \%$ \\
\hline & $\begin{array}{l}\text { Purchasing } \\
\text { intention }\end{array}$ & $\begin{array}{l}\text { Intention of the user to buy from } \\
\text { the website }\end{array}$ & 9 & $12.5 \%$ \\
\hline \multirow[t]{7}{*}{ 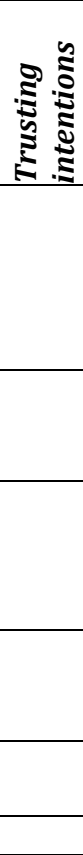 } & $\begin{array}{l}\text { Willingness to } \\
\text { take risks }\end{array}$ & $\begin{array}{l}\text { willingness of the user to take risks: } \\
\text { disclosure of personal information, } \\
\text { spend money to buy from the site, } \\
\text { delivery time, not correspondence } \\
\text { with the delivered product. }\end{array}$ & 9 & $12.5 \%$ \\
\hline & $\begin{array}{l}\text { Willingness to } \\
\text { depend of the } \\
\text { website }\end{array}$ & $\begin{array}{l}\text { The user can rely on the website } \\
\text { service in case of problems; the } \\
\text { website is the first reference to the } \\
\text { customer in case of difficulty } \\
\text { related to the website offer. }\end{array}$ & 5 & $7 \%$ \\
\hline & $\begin{array}{l}\text { Intention to } \\
\text { revisit the } \\
\text { website }\end{array}$ & $\begin{array}{l}\text { Intention of the user to return to } \\
\text { the website }\end{array}$ & 5 & $7 \%$ \\
\hline & $\begin{array}{l}\text { Intention of } \\
\text { recommending } \\
\text { the website }\end{array}$ & $\begin{array}{l}\text { Consumer predisposition to } \\
\text { recommend the web site to other } \\
\text { users, Willingness to the user to } \\
\text { promote the site with others }\end{array}$ & 5 & $7 \%$ \\
\hline & $\begin{array}{l}\text { Willingness to } \\
\text { share personal } \\
\text { data }\end{array}$ & $\begin{array}{l}\text { The user is predisposed to } \\
\text { communicate personal data to the } \\
\text { website }\end{array}$ & 4 & $5.5 \%$ \\
\hline & $\begin{array}{l}\text { Willingness to } \\
\text { follow advice }\end{array}$ & $\begin{array}{l}\text { predisposition of the consumer to } \\
\text { request the advice of the website }\end{array}$ & 3 & $4.1 \%$ \\
\hline & Total & & 72 & $100 \%$ \\
\hline
\end{tabular}

The next part will be devoted to identifying the different facets inherent to social presence on a retail website that may affect consumer trust in this website.

\section{The Importance of Online Perceived Social Presence}

The analysis of verbatim showed that social presence is a determinant of trust in a retail website. Furthermore, results proved that there are two levels of online social presence. The first level is attributed to the commercial website. The second is at the user's relationship with other users of this website. By studying the nature of social presence, it seems that it fills the role of a catalyst in the formation of consumer trust in the merchant website.

\section{Perception of the Social Aspect of a Website}

Social presence is perceived as the psychological feeling of being present with a real vendor. This feeling comes from the emotion during the interaction with the website. It is an emotional exchange established between the user and the commercial website giving him a sense of affinity, friendliness and reassuring about the reliability of the website "The means of contact convey to me a feeling of affinity, 
friendliness with the website. The feeling of being in good hands" (interviewee 5).

In fact, some consumers tend to compare the online purchasing to the off-line purchasing. They want subconsciously transposed the sympathy that they feel (conviviality, warmth) during an off-line transaction, to an online shopping experience "I like the website which user friendly, where the atmosphere is warm" (interviewee 24).

The consumer is sensitive about a feeling of face-to-face with a physic vendor. In procurement, he emphasizes physical contact as a vector of trust"... nothing that shaking hands with someone is completely different from talking through a screen. This is very different because there are signs and facial expressions that reflect the reliability of the merchant as his way of speaking, his gestures, the tone of his speech which everything can translate his unconscious. On the other side, on the internet, you deal with a machine, something fixed, without soul, without feeling" (interviewee 18). This feeling of "live" serves to mitigate the distrust of others about the true "identity" of this website. It is a positive sign generator of the site seriousness and honesty "Through direct contact with a staff member of the company, you feel like you're actually in the process of dealing with people who are serious and honest and not with a screen that could hide a disaster "(interviewee 24).

In contrast, the user refuses to trust a website until he has not identified the human traces of people who are responsible, "I can't trust this site since I don't see that behind this website the real merchant! The owner of this online store, I don't know him, I can't see him. The guy or even someone from the company has come to present his offer, but nobody appears to me. It creates doubts for me" (interviewee 24).

In the absence of such traces, the interviewee expresses a state of anxiety that dampen his willingness to trust the site "From my side, I feel that there is someone who works behind that could repair the malfunction of the service that I paid. So, I had this feeling of being alone, lost, trapped in a place where nobody could hear me" (interviewee 27).

To place their trust, interviewees went as far as claiming the need to feel really face to the seller at the time of their interaction with the merchant website "I want to live the ambiance where merchants display their wares and entice customers by their discourse "(interviewee 23). They explain this by the sense of comfort that they could carry a human exchange "...The difference is that on the net you don't feel feelings, there is no emotional exchange, that are cold, so the merchant on the net must convey to me the same sense of comfort that I could have if I was dealing with a real dealer "(interviewee 18). In fact, the human presence on a website is a comfort to other users by reassuring them mostly against two risks: the risk related to the security of payment and the risk related to the product ordering "there must have this sensation of human contact is priority to reassure customers and especially with the risk of fraud in the payment of more than the risk that the product supplied does not match the ordered product "(interviewee 16).

Thus, during their interaction with a merchant website, many respondents tend to humanize the website by attribute it the role of a vendor that who will satisfy their needs "I want to feel that I am in front of a salesperson or a technician that I could request any information that I need "(interviewee 23).

\section{Manifestations of Social Presence on the Website}

\section{The Website Data}

This sense of human presence can be felt through the detailed information during the periods of price promotions. In effect, displaying both for a same product, a new cheaper price than the old price, the user has the sense to negotiate price, haggle with a real seller "In addition, I must have the feeling of being in front of a spirited seller to negotiate the price of a product 
that interests me, this could be achieved through the proposed former price, then a new discounted price "(interviewee 24).

\section{The Animations on the Website}

Through some billboard flashing exposed on the website, the user feels a real sale atmosphere created by merchants "... I liked the billboard that there is flashing, animation where is written buy-sell, it makes me feel like I'm in a market, I can imagine the place where merchants display their wares and entice customers by their speech "(interviewee 23).

\section{Human Photos}

The human presence can be regarded via the human pictures posted on the site. These pictures may represent either the company team or human models representing into the site. By finding the pictures of the company team, the user will feel at ease in the presence of human faces which he always used to see "it's as I'm with people I know and I am sure they will never make me evil "(interviewee 20). Also, this can be interpreted as a website credibility cue that is committed to view the photos of its members by providing the necessary information "It will be really wise and reassuring about the credibility of the website submitting photos of the team that manages the company where it is written beside or below the text describing each member and its main function better yet a dedication from him to their customers and all visitors of the website "(interviewee 24).

Other interviewees feel a human presence through people photos (models) on the website. Through their smiles, a user (interviewee 11) says that he feels comforted "I wish we were exposed to models with the products in the hands for example that show us this plasma screen in their living rooms, so I'll have an idea of what it will be at home, I don't know how to explain it, but the smile on people's faces comfort me, I like it.

\section{The Personalized Welcome}

The customized welcome can be seen as a form of benevolent presence on the website that cares about the welfare of its client. The website surrounds the consumer of its favorite themes, "I feel that the webmaster is present, the home page is exclusively made for me, and it contains my favorite subjects, my preferences" (interviewee 18).

\section{Virtual Agents}

The existence of avatars on the website is assimilated by the user as the human being's presence. The virtual agent provides users the feeling of interpersonal interaction "I discussed with Emma, the agent on the IKEA website, I even dredged, I took for a real woman (smile), it was difficult for me to assimilate Emma to an avatar "(interviewee 30).

\section{Frequently Asked Questions (FAQ)}

The customer claims a more pronounced need to feel the "real" presence of the merchant when he faces with a retail website. This feeling of human presence is achieved through the space "frequently asked questions (FAQ) "where the site offers some answers to commonly asked questions by users who want to learn more about the offer of the website. Across the sensation of human presence, the users perceive the website as attentive to their concerns and facilitating further obtaining the information required "For example, the FAQ would be a plus especially if it is a website that you don't know, for example a new site. So this direct connection with the website might motivate me to trust it because it reassures me that this is a real website. Thus, I can inform directly on the site without having to seek information elsewhere. This contact could bring the client company that sells through its website; it makes me forget the virtuality and gives me the impression of "live"(interviewee 28). 


\section{Instant Messaging}

Internet users have raised the instant messaging technology as a source of creating a sense of human presence. According to them, this interacting mean can send them the psychological state of the other through the exchange of texts and the description of his emotional state using emoticons appearing.

For consumers, these elements can substitute a face-to-face interaction by giving them the same impression. Using this technology, the user will more perceive the competence of the website, the degree of honesty and dedication to its customers "In fact, instant messaging with the webmaster for example make you feel that there is someone who is with you, you feel more his trustworthiness because you can see his reactions through his writings and his face grimaces through the emoticons that appear ... this gives me an idea if the website is serious or not, helpful or not, etc. "(interviewee 27). Therefore, in the presence of this "humanized" feeling during interacting with the website, the consumer is better informed about every detail required and then he will be able to give more easily his trust to the retail website.

\section{The Number of Entries}

The analysis of verbatim reveals that users have different perceptions of social presence, at least with varying intensities of a user to another. Indeed, some interviewees involved the number of registered members as an indicator of social presence. It refers to the feeling of belonging to a community within a website. This membership is a source of reassurance to the user about the trustworthiness of the website in an argument with the crowd as a source of wisdom for the individual.

In another way, by looking the registered number of users on the website, a consumer feels surrounded by other people who interact with this retail site. This simultaneous interaction is a persuasive indication to the consumer about the reliability of the website which has power to attract so many people who giving it their trust "The first point of trust is the number of people listed on this website, it must display the accounts of users which contains "(interviewee 18).

\section{Discussion Forums}

Another form of human presence is expressed by the respondents relating to the psychological sensation of presence in a group of people. Surowiecki (2004) starts from the axiom of bounded rationality to apply that information in aggregated groups occur in decisions. These collective judgments are often considered better than individual judgments which the author calls "collective intelligence". Thus, a user will feel the presence of other users, who have chosen to become members of a website, will be more inclined to see it as worthy of his trust "...this provides clues that is if I feel the presence of people on this website, I could deduce that it is recognized, it was able to convince a lot of people so it encourages me to trust him "(interviewee 20).

Thereby the technical forums monitored by the company and included in the commercial website make the user feel in a social group along he discusses the smallest details about the website (supply, quality, reputation ...). Thus, freely exchanging ideas with other users, different opinions can be collected both positive and negative about the offer on the website. As a result, the user will realize the level of transparency of the website and will be more inclined to give it his trust "But when you feel that there are real comments and real answers that say as much good as evil on product, for example, you find people who said "it's failing, it's rotten" while, others extolling the virtues of the product. When you find this mixture of opinion, you feel that the website is honest and that it is credible and so you could then give it your trust more easily "(interviewee 27).

\section{Social Networks}

By creating its official page on some social networks like Facebook or Twitter, the 
company provides to its customers the opportunity to get closer to its offer through interactions between consumers thanks to social networks. In fact, the user feels the presence of other people who will evaluate the company's offer or details in relation to this website; For them, it is a professional website that is always listening to its customers "I like the headings" join us "or" join our website "by creating an account on Facebook or Twitter for example, it is like being in a group of people who share the same place and have common interests. At this point, you feel that the site is an expert, it follows the new trends, it is still there with its customers, but he is not afraid of criticism which it receives from its clients "(interviewee 25). Therefore, it seems that the perceived social presence on a commercial website comes further increased consumer trust in this website. For this purpose, we can assume that social presence has a positive effect on trust toward a retail website.

By way of summary, the following table summarizes the manifestations of social presence online as determinants of trust in a merchant website, its occurrence frequency of occurrence in the transcript and the citations' percentages of the citation that related thereto:

Table 2: Determinants of Trust in a Dealer Website: Manifestations of Social Presence, Frequencies and Percentages

\begin{tabular}{|l|r|r|}
\hline $\begin{array}{l}\text { Manifestations of social } \\
\text { presence }\end{array}$ & $\begin{array}{l}\text { Frequency of citations } \\
\text { in the corpus }\end{array}$ & $\begin{array}{l}\text { Percentage of citations in } \\
\text { the corpus }\end{array}$ \\
\hline Data & 12 & $15,38 \%$ \\
\hline Animations & 2 & $2,56 \%$ \\
\hline Human photos & 12 & $15,38 \%$ \\
\hline personnalized welcome & 4 & $5,128 \%$ \\
\hline virtual agents & 6 & $7,692 \%$ \\
\hline FAQ & 4 & $5,128 \%$ \\
\hline Instant messaging & 14 & $17,94 \%$ \\
\hline Discussion forums & 10 & $12,82 \%$ \\
\hline Number of entries & 6 & $7,692 \%$ \\
\hline Social networks & 8 & $10,25 \%$ \\
\hline Total & 78 & $100 \%$ \\
\hline
\end{tabular}

From the table above, it is clear that the instant messaging, the human photos and data especially about prices represent the heavier forms in determining trust in a retail website. These results are diagrammed using the following histograms illustrating these results. Indeed, the technology of second life (virtual agents) is the future of the web. In such a short time, it becomes an important source of social presence and it involves in the formation of trust. This is consistent with the results of the study conducted by Lemoine and Notebaert (2009) that confirms its importance in trust formation. Also, online companies are required to register on social network continuing to conquer the web. This sense of social presence is regarded by users of social networks: Facebook, Twitter, My space,... as a determining factor in the development of trust in a retail website. 


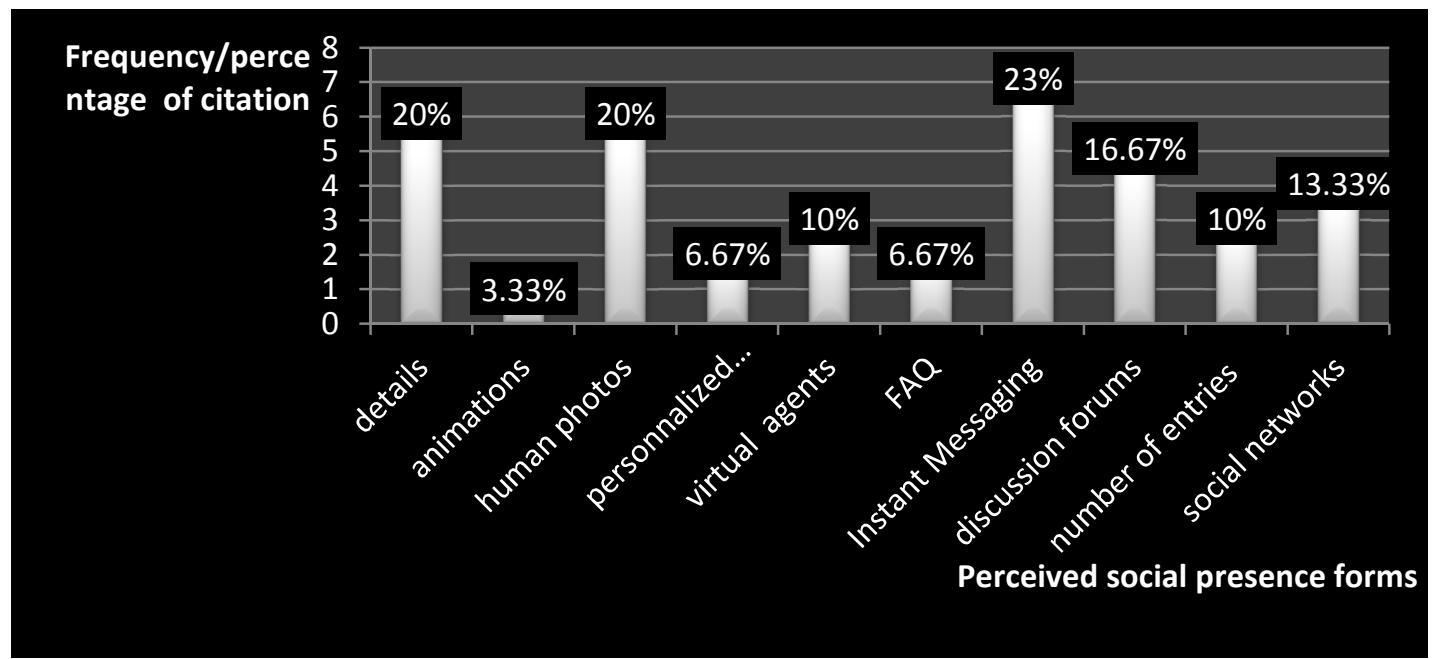

Fig 2. Illustration of the Effect of Different Sources of Social Presence on Trust in a Retail Website

Finally, the main results of this exploratory research can be represented as follows-:

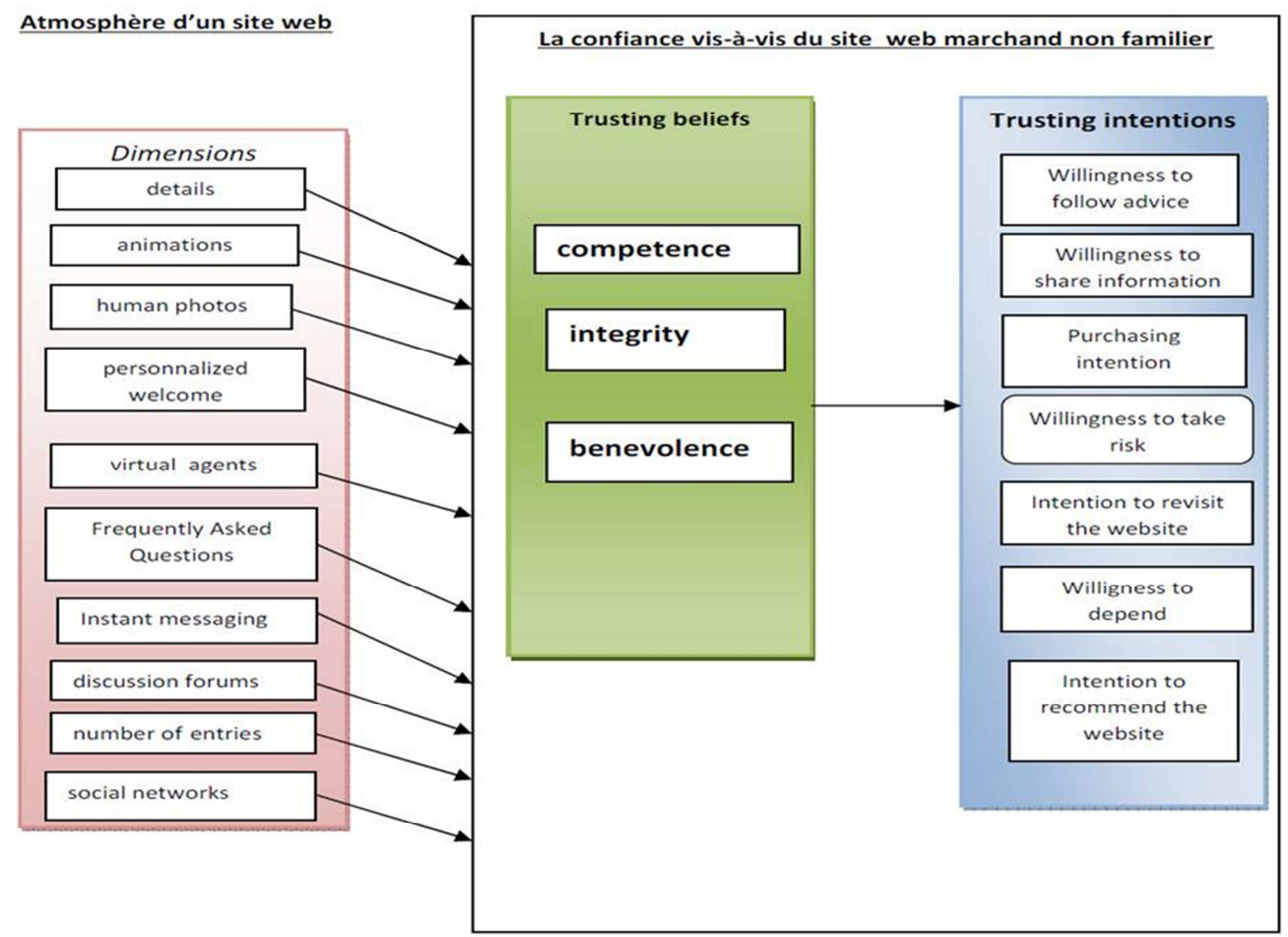

Fig 3. The Conceptual Model of the Research 


\section{Conclusion and Discussion}

First time, through an exploratory qualitative study, this research explored a particular level of online trust namely trust in a commercial website. In contrast to other levels of trust established in the context of electronic commerce (e.g. trust in e-commerce, trust in electronic commerce transactions), this particular form of trust sparked several debates that challenged its existence and the validity of its foundations. During this research, we defined trust in a retail website describing its theoretical foundation and its various dimensions.

Secondly, this article highlights the importance of perceived social presence on a commercial website. We projected light on various forms of social presence specifying each time its different forms in the context of virtual exchange.

Then, we have demonstrated a positive relationship combining trust in a commercial website and social presence perceived by the user through this website. Indeed, it is clear that the human sense of presence felt by the consumer through a mediated communication has a specific importance in the formation of trust in a commercial website. This can be justified by the nature of trust which requires the need for contact (Handy, 1995) but also by the characteristics of the virtual context where uncertainty and risk are more obvious. Subsequently, the feeling of being socially surrounded or be accompanied by another person is reassuring for consumers and comfort them in such exchange context devoid of physical contact. Consequently, this feeling of being there with someone else via a media encourage consumers to have trust in this medium. Thus, the main objective of this research was to reveal the role of perceived social presence in trust formation toward the website.

The results of this research have allowed:

- To become more familiar with the concept of trust in a retail web site as well as the concept of social presence. Indeed, this study aims for dissecting both the concept of social presence and the notion of trust in a commercial website by identifying all their manifestations.

- To approve the relevance of online social presence on a retail website in the development of trust in this website. In fact, consumers are attentive to any stimulus on the virtual shopping environment. So, website designers must attenuate the uncertainty felt by consumers and reduce the perceived risks by introducing human traces on the website in order to ensure consumers. This will encourage them to trust the website. To our knowledge, very few works focused on the study of trust in a website. In addition, few studies have addressed the impact of social presence on online trust in a general way. They were limited to empirically testing the link between the two concepts without mentioning the various forms of online social presence. Thus, on the one hand, this research has discussed in-depth the specifics of a particular form of online trust: trust in a website. On the other hand, this research has scrutinized the mechanisms of the concept of social presence on a website deepening its various components which may affect consumer trust towards the website.

- To Highlight the affective component of trust that is "benevolence" which remains congruent with the context of online shopping, despite the skepticism of some researchers (e.g. Chouk and Perrien, 2004; Chouk, 2010) about its relevance in this particular purchasing context.

The results are encouraging professionals to focus more on the design of their websites. In fact, the results of the study provide a consumer trends mapping giving importance to certain factors constituting social presence through techniques such as instant messaging, FAQ, forums, animations, data website, the number of registered on the website, human photos, personalized welcome and virtual agents. The variety of these techniques offers to marketers a high flexibility adapting both 
to their aims and to their budget constraints. Managers may use these tools to maximize customer satisfaction and maintain the sustainability of their activities on the Internet.

This study presents a major limitation related to the generalization of the obtained results. Optionally, an empirical evaluation of these results is strongly requested to statistically validate the results retained.

\section{References}

Bartikowski, B., Chandon, J.- L. \& Müller, B. (2008). "Mesurer la Confiance des Internautes par Rapport aux Sites Web Marchands: Adaptation de McKnight, Kacmar et Choudhury (2002), http://www.escpeap.net/conferences/mar keting/2008_cp/Materiali/Paper/Fr/Barti kowski_Chandon.

Bartikowski, B., Chandon, J. L. \& Müller, B. (2010). 'Mesurer la Confiance des Internautes : Adaptation de McKnight, Choudhury and Kacmar (2002),' Journal of Marketing Trends, 1, (1), 11-25.

Biocca, F., Harms, C. \& Burgoon, J. K. (2003). "Towards A More Robust Theory and Measure of Social Presence: Review and Suggested Criteria," Presence Teleoperators and virtual environements, 12, (5), 456-480.

Biocca, F., Harms, C. \& Gregg, J. (2001). "The Networked Minds Measure of Social Presence: Pilot Test of the Factor Structure and Concurrent Validity," In Proceeding of Presence 2001, Philadelphia, USA.

Blau, P. M. (1964). Exchange and Power in Social Life, New York: John Wiley \& Sons.

Brial, B. (2010). "La Présence Humaine sur les Sites Marchands : Une Recherche Exploratoire pour l'élaboration d'une Typologie de Consommateurs," Actes du Congrès International de l'Association Française du Marketing, Le Mans, Mai. building trust? Photos on e-commerce websites and consumer trust.
Chouk, I. (2010). Achat sur Internet: Comment Susciter la Confiance?, Entreprise et Management, L'Harmattan.

Chouk, I. \& Perrien J. (2004). "les Facteurs Expliquant la Confiance du Consommateur lors d'un Achat sur un Site Marchand : Une Étude Exploratoire," Décisions Marketing,35,75-86.

Chouk, I. \& Perrien, J. (2005). 'La Confiance $\mathrm{du}$ Consommateur vis-à-vis d'un Marchand,' Revue Française du Marketing, 5,(205), p.1-15.

Corbitt, B. J., Thanasankit ,T. \& Yi, H. (2003). "Trust and E-Commerce: A Study of Consumer Perceptions," Electronic Commerce Research and Application, 2, 203215.

Descamps, M. A. (1987). 'Manuel de Méthodologie en Sciences Humaines," Université René-Descartes, Laboratoire d'éthique médicale et biologique.

Dwyer, F. R., Churr, P. H. \& Oh, S. (1987). "Developing Buyer-Seller Relationships," Journal of Marketing, 5,(1), 11-27.

Forrest, E. \& Mizerski, R. (1996). 'Interactive Marketing: The Future Present,' Chicago: NTC Business Books.

Fortin, D. R. \& Dholakia, R. R. (2005). "Interactivity and Vividness Effects on Social Presence and Involvement with a Web-Based Advertisement," Journal of Business Research, 58 387-396.

Fukuyama, F. (1995). Trust: Social Virtues and the Creation of Prosperity, NY: Free Press.

Garau, M. (2006). "Selective Fidelity: Investigating Priorities for the Creation of Expressive Avatars," Avatars at Work and Play,34,17-38.

Gefen, D. (2000). "E-commerce: The Role of Familiarity and Trust," The International Journal of Management Science, 28 725737. 
Gefen, D., Karahanna, E. \& Straub, D. W. (2003). "Trust and TAM in Online Shopping: An Integrated Model," MIS Quarterly (27) 1, 51-90.

Gefen, D. \& Straub, D. W. (2004). "Consumer Trust in B2C E-Commerce and the Importance of Social Presence: Experiments in E-Products and E-Services," Omega, 32,(6),407-424.

Goffman, E. (1959). The Presentation of Self in Everyday Life, New-York: Harper and Row.

Green, N. (1993). 'Can Computers Have Genders?,' Paper presented at the annual conference of the International Communication Association, Washington, D.C.

Handy, C. (1995). "Trust and the Virtual Organization," Harvard Business Review 73,(3), 40-50.

Hassanein, K., \& Head M. (2007). "Manipulating Perceived Social Presence through the Web Interface and its Impact on Attitude towards Online Shopping," International Journal of Human-Computer Studies, 65, (8), 689-708.

Hoffman, D. L., Novak, T. P. \& Peralta, M. A. (1999). "Building Consumer Trust Online," April, Communications of the ACM, 42,(4),80-85.

Hsu, C. J. (2008). "The Development of a Conceptual Model for Online Trust," Institute for Integrated and intelligent systems (IIIS), Griffirth UniversityAustralia, http://iceb.nccu.edu.tw/CMS/APDSI2008/

Huguet, P., Galvaing, M. P., Monteil, J. M. \& Dumas, F. (1999). "Social Presence Effects in the Stroop Task: Further Evidence for an Attentional View of Social Facilitation," Journal of Personality and social psychology, 77, 1011-1027.

Jarvenpaa, S. L. \& Tractinsky, N. (1999). "Consumer Trust in an Internet Store: A Cross-Cultural Validation," Journal of Computer-Mediated Communication, 5, (2), 1-35.
Karahanna, E. \& Straub, D. W. (1999). "The Psychological Origins of Perceived Usefulness and Ease-of-Use," Information \& Management, 35, (4) 237-250.

Kelley, H. H. (1979). 'Personal Relationships: Their Structure and Processes,' New Jersey: Lawrence Erlbaum Associates.

Kelley, H. H. \& Thibaut J. W. (1978). "Interpersonal Relations a Theory of Interdependence," New York: Wiley.

Khalifa, M. \& Shen, N. (2004). "System Design Effects on Social Presence and Telepresence in Virtual Communities," Proceeding of the Twenty-fifth International Conference on Information Systems. Washington.

Kim, J. H., Kim, M. \& Lennon, S. J. (2009). "Effects of Web Site Atmospherics on Consumer Responses: Music and Product Presentation," Direct Marketing: An International Journal, Jan, 3,(1), 4-19.

Kumar, N. \& Benbasat, I. (2002). "ParaSocial Presence: A Re-Conceptualization of Social Presence to Capture the Relationship between a Web Site and Her Visitors," Proceedings of the Thirty-fifth Hawaii International Conference on System Sciences. Maui.

Lemoine, J. F. \& Notebaert, J. F. (2009). “L'Influence des Agents Virtuels sur la Confiance des Internautes vis-à-vis d'un Site Web," Proceedings of the 11th Inernational Business Information Management Association (IBIMA) Conference, 4-6 january, Cairo, Egypt.

Luhmann, N. (1979). Trust and Power, Chichester, Wiley.

Mayer, R., Davis, J. \& Schoorman, F. (1995). "An Integrative Model of Organizational Trust," Academy of Management Review, 20, (3), 709-734.

McKnight, D. H. \& Chervany, N. L. (20012002). "What Trust Means in E-Commerce Customer Relationships: An Interdisciplinary Conceptual Typology," 
International Journal of Electronic Commerce 6,2, 35-59.

McKnight, D. H., Choudhury, V. \& Kacmar, C. (2002). "The Impact of Initial Consumer Trust on Intentions to Transact with a Web Site: A Trust Building Model," Journal of Strategic Information Systems, 11, 297-323.

McKnight, D., Cummings, L. \& Chervany, N. (1998). "Initial Trust Formation in New Organizational Relationships," Academy of Management Review, 23, (3), 473-490.

Moon, Y. (2000). "Intimate Exchanges: Using Computers to Elicit Self-Disclosure From Customers," Journal of Consumer Research, 26, 323-339.

Moorman, C., Zaltman, G. \& Deshpande, R. (1992). "Relationships between Providers and Users of Market Research: The Dynamics of Trust within and between Organizations," Journal of Marketing Research, 29, 314-328.

Mucchielli , A. (1991). 'Les Méthodes Qualitatives, Que Sais-Je ?,' Paris, PUF.

Nass, C., Fogg, B. J. \& Moon, Y. (1996). "Can Computers be Teammates?," International Journal of Human-Computer Studies, 45, (6), 669-678.

Nass, C., Moon, Y. \& Green, N. (1997). “Are Machines Gender-Neutral? Gender Stereotypic Responses to Computers," Journal of Applied Social Psychology, 27, (10), 864-876.

Nass, C., Steuer, J., Tauber, E. \& Reeder, H. (1993). 'Anthropomorphism, Agency and Ethopoeia: Computers as Social Actors,' INTERCHI'93 conference of the ACM/SIGCHI and the IFIP, Amsterdam, Netherlands.

Nass, C., Steuer, J. \& Tauber, E. (1994). "Computers are Social Actors," CHI'94 conference of the ACM/SIGCHI, Boston, MA.

Nass, C. I., Moon, Y., Fogg, B. J., Reeves, B. \& Dryer, D. C., (1995). "Can Computer Personalities Be Human Personalities?,"
International Journal of Human-Computer Studies, 43, 223-239.

Pavlou, P., Liang, H. et Xue, Y.( 2005). 'Understanding and Mitigating Uncertainty in Online Environments: A Longitudinal Analysis of the Role of Trust and Social Presence,' Proceedings of Academy of Management Conference. Honolulu,

Pras, B., Evrard, Y. \& Roux, E. (2003). "Market: Etudes et Recherches en Marketing," 3ème édition, Dunod.

Reichheld, F.F, \& Schefter P. (2000). "ELoyalty: Your Secret Weapon on the Web," Harvard Business Review, 78, 105-13.

Rempel, J. K., Holmes, J. G. \& Zanna, M. D. (1985). "Trust in Close Relationships," Journal of Personality and Social Psychology, 49, 95- 112.

Riegelsberger, J. \& Sasse, M. A. (2002). 'Trust Builders and Trust Busters,' Proceedings of the e-Commerce, e-Business, e-Government,Zurich, Switzerland, 17-30.

Riegelsberger, J., Sasse, M. A. \& McCarthy, J. D. (2003). "Shiny Happy People Building Trust? Photos on E-Commerce Websites and Consumer Trust," Proceedings of CHI, 5, (1), 121-128.

Scarpetta, F. (2008). "Practices to Display Social Presence: A Study in a Shared Mediated Environment," PsychNology Journal, 6,(1), 27-59.

Schimke, D., Stoeger, H. \& Ziegler, A. (2007). "The Relationship between Social Presence and Group Identification within Online Communities and its Impact on the Success of Online Communities," D. Schuler (ed.), Online communities and social concept, HCII2007, LNCS 4564 (pp. 160168). Heidelberg: Springer-Verlag.

Schoorman, F., Mayer, R. \& Davis, J. H. (2007). "An Integrative Model of Organizational Trust: Past, Present and Future," Academy of Management Review, 32, (2), 344-354. 
Schroeder, R., Steed, A., Axelsson, A. S., Heldal, I., Abelin, Å., Wideström, J., Nilsson, A. \& Slater, M. (2001). "Collaborating in Networked Immersive Spaces: As Good as Being there Together?," Computers \& Graphics, 25, 781-788.

Schwartz, E. (1997). 'Webonomics,' New York: Broadway.

Short, J., Williams, E. \& Christie, B. (1976). "The Social Psychology of Telecommunications," Londres, John Wiley and sons.

Spagnolli, A. \& Gamberini, L. (2005). “A Place for Presence. Understanding the Human Involvement in Mediated Interactive Environments," PsychNology Journal, 3,(1), 6- 15.

Spencer, D. (2001). "Constructivism through Social Presence and Swift Trust: Facilitation and Collaboration within Online Learning Networks," Proceedings of the Seventh Americas Conference on Information Systems. Boston.

Steinbrück, U., Schaumburg, H., Duda, S. \& Krüger, T. (2002), 'A Picture Says More than a Thousand Words-Photographs as Trust Builders in Ecommerce Web Sites,' Actes du CHI, 20 au25 avril, Minneapolis, Minnesota, 748-749.

Steuer, J. (1992). "Defining Virtual Reality: Dimensions Determining Telepresence," Journal of Communication, 42, 4, 73-93.

Surowiecki, J. (2008). La Sagesse des Foules, Paris, Jean-Claude Lattès.
Thabet, M. \& Zghal, M. (2012). 'Influence de l'atmosphère d'un Site Web Marchand sur la Confiance du Consommateur Tunisien lors d'un Achat en Ligne : Étude Exploratoire,' Proceedings of the 18th Inernational Business Information Management Association (IBIMA), ISBN:978-0-9821489-7-6, May, 9-10,2012, Istanbul, Turkey, 2069-2091.

Thibaut, J. W. \& Kelley, H. H. (1959). "The Social Psychology of Groups," New York: Wiley.

Tu, C. H. (2002a). "The Measurement of Social Presence in an Online Learning Environment," International Journal of ELearning, 1,(2), 34-45.

Tu, C. H. (2002b). "The Relationship between Social Presence and Online Privacy," Internet and Higher Education, 5, 293-318.

Tu, C. H. \& McIsaac, M. (2002). "The Relationship of Social Presence and Interaction in Online Classes," American Journal of Distance Education, 16 (3), 131 150.

Wang, L. C., Baker, J., Wagner, J. A. \& Wakefield, K. (2007). "Can a Retail Web Site be Social?," Journal of Marketing, 71, 143157.

Zhu, L., Benbasat, I. \& Jiang, Z. (2006). "Investigating the Role of Presence in Collaborative Online Shopping," Proceedings of the Twelfth Americas Conference on Information Systems. Acapulco. 
Appendix . Sample Profile

\begin{tabular}{|c|c|c|c|}
\hline Interviewees & Gender & Age & Socio-professional category \\
\hline 1 & Male & 40 & Engineer in telecommunication sciences \\
\hline 2 & Male & 48 & Translator \\
\hline 3 & Male & 32 & Assistant professor of mathematics \\
\hline 4 & Male & 28 & Employee in an insurance group \\
\hline 5 & Male & 33 & Supervisor in a call center \\
\hline 6 & Male & 35 & $\begin{array}{l}\text { Company manager transcription services for } \\
\text { Francophone countries }\end{array}$ \\
\hline 7 & Male & 38 & Owner and manager of a call center \\
\hline 8 & Male & 34 & Technical manager in a telephone operator \\
\hline 9 & Male & 32 & Webdesigner \\
\hline 10 & Female & 31 & Employee in the post office \\
\hline 11 & Female & 36 & General practitioner \\
\hline 12 & Female & 31 & Agency head in a telephone \\
\hline 13 & Female & 36 & Assistant professor of French literature \\
\hline 14 & Male & 55 & Responsible in a communication agency \\
\hline 15 & Male & 32 & Marketing director \\
\hline 16 & Male & 41 & Designer \\
\hline 17 & Male & 39 & Supervisor of a call center \\
\hline 18 & Male & 32 & Computer Engineer \\
\hline 19 & Male & 30 & Computer engineer \\
\hline 20 & Male & 34 & Production Manager \\
\hline 21 & Female & 43 & Employee of a bank \\
\hline 22 & Male & 32 & $\begin{array}{l}\text { Sales manager at one Internet service } \\
\text { provider }\end{array}$ \\
\hline 23 & Male & 40 & Owner of a textile factory \\
\hline 24 & Male & 31 & Journalist \\
\hline 25 & Male & 42 & Manager of a computer box \\
\hline 26 & Female & 48 & Art teacher \\
\hline 27 & Female & 34 & Electronic engineer \\
\hline 28 & Male & 37 & Computer engineer \\
\hline 29 & Male & 33 & Computer Engineer \\
\hline 30 & Male & 25 & Student in mechanical engineering \\
\hline
\end{tabular}

